\title{
BMJ Global Health How antibiotics are used in pig farming: a mixed-methods study of pig farmers, feed mills and veterinarians in Thailand
}

\author{
Angkana Lekagul, ${ }^{1,2}$ Viroj Tangcharoensathien, ${ }^{2}$ Anne Mills, ${ }^{3}$ Jonathan Rushton, ${ }^{4}$ \\ Shunmay Yeung ${ }^{1,3}$
}

To cite: Lekagul A,

Tangcharoensathien V, Mills A, et al. How antibiotics are used in pig farming: a mixedmethods study of pig farmers feed mills and veterinarians in Thailand. BMJ Global Health 2020;5:e001918. doi:10.1136/ bmjgh-2019-001918

Handling editor Peter MacGarr Rabinowitz

- Additional material is published online only. To view please visit the journal online (http://dx.doi.org/10.1136/ bmjgh-2019-001918).

Received 23 August 2019 Revised 20 December 2019 Accepted 22 December 2019

Check for updates

(c) Author(s) (or their employer(s)) 2020. Re-use permitted under CC BY-NC. No commercial re-use. See rights and permissions. Published by BMJ.

${ }^{1}$ Faculty of Infectious and Tropical Diseases, London School of Hygiene and Tropical Medicine, London, UK ${ }^{2}$ International Health Policy Program, Ministry of Public Health, Nonthaburi, Thailand ${ }^{3}$ Faculty of Public Health and Policy, London School Hygiene and Tropical Medicine, London, UK

${ }^{4}$ Institute of Infection and Global Health, University of Liverpool, Liverpool, UK

Correspondence to Ms Angkana Lekagul; angkana@ihpp.thaigov.net

\section{ABSTRACT}

Background Rising global concern about antimicrobial resistance has drawn attention to the use of antibiotics in livestock. Understanding the current usage of antibiotics in these animals is essential for effective interventions on the optimisation of antibiotic use. However, to date few studies have been conducted in low- and middle-income countries. This study aimed to explore the use of antibiotics and estimate the total amount of antibiotics used in pig production in Thailand.

Methods This was a mixed-methods study including a cross-sectional questionnaire-based survey of 84 pig farmers, secondary analysis of data from a survey of 31 feed mills to estimate the amount of antibiotics mixed in pig feed and interviews with five veterinarians involved in the feed mill industry to gain an understanding of medicated feed production.

Findings Half of the farmers reported using antibiotics for disease prevention. Use was significantly associated with farmers' experience in raising pigs, farm income, having received advice on animal health and belonging to a farm cooperative. The estimated total amount of active ingredients mixed into medicated feed for pigs for the whole country was 843 tonnes in 2017. Amoxicillin was the most commonly used antibiotic reported by both pig farms and feed mills. The use of Critically Important Antimicrobials including colistin was common, with onethird of farmers reporting their use as oral or as injectable medication, and accounting for nearly two-thirds of antibiotics contained in medicated feed.

Conclusion A majority of antibiotics used in Thai pig farms belonged to the category of Critically Important Antimicrobials. Progressive restriction in the use of antibiotics in pigs is recommended through using prescriptions to control the distribution of certain antibiotics. The government should strengthen veterinary services to improve access of farmers to animal health advice and explore alternative interventions.

\section{BACKGROUND}

Rising global concern about antimicrobial resistance $(\mathrm{AMR})^{\mathrm{i}}$ has drawn attention to the

${ }^{\mathrm{i}}$ In general, this study focuses on antibiotics. The

\section{Key questions}

What is already known?

- Rising global concern about antimicrobial resistance has drawn attention to the use of antibiotics in animals, in particular the use of last-resort antibiotics normally reserved for severe infections in humans.

- Low- and middle-income countries are large livestock producers and consumers. There are many studies about the use of antibiotics in livestock in high-income countries yet very few have been conducted in low- and middle-income countries.

What are the new findings?

- Over half of the farmers used antibiotics for disease prevention in pig production.

- The total amount of active ingredients mixed into medicated feed for pigs was estimated to be 843 tonnes in 2017.

- Amoxicillin was the most common antibiotic used for disease prevention and mixed into medicated feed.

- Half the oral and injectable antibiotics used in farms and two-thirds of antibiotics added in medicated feed belonged to the category of Critical Important Antimicrobials (CIA).

\section{What do the new findings imply?}

- Alternative approaches need to be sought to maintain herd health and productivity in order to protect the effectiveness of antibiotics. These solutions need to be tested and demonstrated to farmers to show their relative cost-effectiveness.

- We recommend progressive restriction in the use of antibiotics in pigs with an emphasis on CIA. This can be achieved by controlling the distribution of certain antibiotics for animal use with medicines available only on prescription. 
use of antibiotics in livestock ${ }^{\mathrm{ii}}$ with an estimated $70 \%$ of the antibiotic consumption in Europe being in the animal sector. ${ }^{1}$ Many of the antibiotics commonly used in animals are categorised as Critically Important Antimicrobials (CIA) for treating humans according the WHO list of Critically Important Antimicrobials for Human Medicine (WHO CIA list). The WHO CIA list categorises Medically Important Antimicrobials into three categories: Important, Highly Important and Critically Important, and further divides the last category (CIA) into 'high priority' CIA including aminoglycosides, aminopenicillins and carbapenems; and 'highest priority' CIA including cephalosporins (third, fourth and fifth generation), glycopeptides, macrolides, polymyxin (colistin) and quinolones. ${ }^{23}$ Of particular concern has been the use of CIA, the last-resort antibiotics normally reserved for the most severe infections in humans. ${ }^{4-6}$ Indeed there is emerging evidence of the threat including a recent report describing the discovery of a plasmid-mediated colistin-resistant gene in commensal Escherichia coli from tests on pigs, pork products and humans in China. ${ }^{7}$

The use of antibiotics in pigs is complex and associated with the interrelating domains of animal health, animal welfare and economics. Antibiotics have been used routinely in farm animal production since the 1950s to treat, control and prevent disease and to increase productivity. Based on the predicted continued rise in global demand for livestock products, global antimicrobial consumption of livestock is predicted to increase by two-thirds over the next 10 years. ${ }^{8}$ Within this sector, antimicrobial consumption is estimated to be highest in pigs, compared with chicken and cattle. ${ }^{8}$ It has been a common practice for decades to use subtherapeutic doses of antibiotics in food-animals for a number of reasons: to control the spread of symptomatic infections between animals in close contact some of which may be subclinically infected; to prevent disease at points of high risk prior to the onset of symptoms, particularly when animals are under stress (eg, extreme weather, post vaccination or moving pen) and to improve production performance. ${ }^{9}{ }^{10}$ In pigs, antibiotics can be applied to whole groups including by mixing antibiotics into feed (medicated feed) or adding antibiotic powder or solution into drinking water (medicated water). ${ }^{11-15}$

In order to design and implement effective interventions that will reduce the unnecessary use of antibiotics in livestock, an understanding of current usage is essential. However, while data are available from high-income countries on the use of antibiotics in pigs, there are few studies from low- and middle-income countries. In 2018, Thailand was the first middle-income country in Asia to publish data on the total consumption of antimicrobials and reported that 3690 tonnes of antimicrobials were used in livestock production in $2017 .{ }^{16}$ However, these data do not help understand use by animal species,

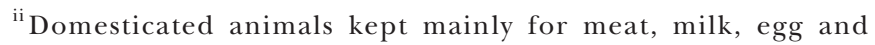
wool production.
}

production system or indications. To address this knowledge gap, this study aimed to explore the use of antibiotics and to estimate the total amount of antibiotics used in pig production in Thailand. A better understanding of antibiotic use in pigs, particularly in low- and middleincome countries, can help design appropriate intervention strategies to optimise the use of antibiotics in livestock production.

\section{METHODS}

Thailand has very diverse livestock production systems, including large agro-industrial conglomerates, contract farming (where the buyer of fatteners also provides piglets, feed, vaccines and technical support to the contract farmers) and smallholder farms. A few large agro-industrial companies dominate the livestock production business with integrated operations including animal breeding, feed production and processing meat products. In 2017, about 19.5 million pigs were raised by 180000 pig farmers, of whom $40 \%$ were smallholder farmers (less than 50 pigs per farm) raising indigenous pig breeds. ${ }^{16} 17$

In order to determine the patterns and total amount of antibiotic use in pig production in Thailand, mixed methods were used: a survey of farmers, secondary data analysis of a survey of feed mill operators and interviews with veterinarians. Data collection was carried out between March 2018 and December 2018.

\section{Survey of pig farmers}

\section{Questionnaire development}

To guide the development of the questionnaire, a literature review and exploratory interviews with five veterinarians were conducted. Following piloting, some questions were modified to suit the local context of pig production. The questionnaire consisted of both closed and openended questions covering general information about the farms (type of farm, number of workers, current number of pigs at different stages, health management), pig production, antibiotic use for prevention of infectious diseases, the source of antibiotics and medicated feed and farmers' knowledge and awareness about antibiotics and antibiotic resistance (online supplementary file 1).

\section{Study site and sample population}

The cross-sectional study was conducted in a province in the central region of Thailand, which has one of the highest pig populations, accounting for about $20 \%$ of total annual Thai pig production. The province has an area of about 5000 square kilometres subdivided into 10 districts, some with many pig and cattle farms, and some with very few. Based on the best available data and discussions with each district health office, the three districts with the highest number of pig farms were purposively selected and within each district, the two subdistricts with the highest number of pig farms were selected. Due to practical and budgetary constraints, a census and random sampling were not possible. 
Selection and recruitment process

Within the six selected subdistricts, all pig farmers were invited to participate in the study via an official letter. Village health volunteers and public health staff in the subdistrict health centres also encouraged pig farmers to participate.

\section{Data collection}

Between March 2018 and December 2018, interviews with pig farmers took place in the local health centres and were conducted face-to-face in Thai by 10 interviewers with a healthcare background, who were provided with basic information about pig farming as well as specific data collection training. Most interviews took between 45 and $60 \mathrm{~min}$. Data were collected on tablets offline and synchronised onto a cloud-based server when the internet was available.

\section{Data management and analysis}

The data were exported into Microsoft Excel and Stata/ SE 15 for cleaning and analysis. Based on the number of pigs on the farm at the time of the study, farms were categorised by size as per the Department of Livestock Development (DLD) definition: smallholder farm (less than 50 pigs), small commercial farm (from 51 to 500 pigs), medium commercial farm (from 501 to 5000 pigs) and large commercial farm (more than 5001 pigs). The farms were grouped by type into farrow-to-finish (breeder, suckling piglet, nursery pig, fattener), fattening (fatteneronly) and breeding (breeder-only). Pig farms were also classified according to whether they held a Good Agriculture Practice (GAP) certificate from the DLD, indicating they had satisfied a certain practice standard. Farms were also classified into a contract or non-contract farm. Contract farmers provide animal housing and labour while the contracting company provides pigs, feed, medicines and technical support to farmers. Non-contract farmers are independent of contracting companies. Pig farms were also grouped based on whether they were members of a district or provincial cooperative.

Descriptive analyses including examination of means and frequencies were conducted to describe the characteristics of participants, reported pig health problems and the use and source of antibiotics on the farm. Univariate analysis was used to assess the association between the dependent variable (the use of antibiotics in pigs) and each independent variable (size of farm, type of farm, etc).

\section{Survey of feed mills}

To estimate the total amount of antibiotics mixed in pig feed in Thailand, we used data from a 2017 national survey of feed mills conducted by the International Health Policy Program (IHPP), Ministry of Public Health, which estimated the total national consumption of medicated feed by food-producing animal species. ${ }^{16}$ The target population was the 238 feed mills registered with the DLD in 2018. IHPP met representatives of the 53 feed mills who were members of the Thai Feed Mill
Association (TFMA) to explain the study in March 2018 prior to sending the survey form via email and fax. The official letter and survey form were also sent to the nonTFMA members (185 feed mills). In May 2018, all nonresponders were followed up by phone.

The respondents were asked to extract the volume of antibiotics added to feeds from the feed production records which were usually kept in an electronic format. They were asked to fill in separate forms for each animal species for the calendar year 2017. For the secondary data analysis for this study, we extracted the data from the forms related to pigs and used the following variables:

- Name of the antibiotic (added to the medicated premix) according to the veterinary anatomical therapeutic chemical (ATGvet) classification system.

- Thailand Food and Drug Administration (Thai-FDA) market authorisation identification number.

- Trade name of the medicated premix and the market authorisation holder.

- Type and amount of the antibiotic added to the feed.

- Stage of pig production for which the medicated feed was intended.

\section{Data management and analysis}

Data from survey forms were entered into in Microsoft Excel and checked for completeness. Descriptive statistical analyses were performed using Stata/SE 15 software. Antimicrobial consumption was measured by kilograms of active ingredient per year (2017) and calculated as the volume of active ingredients multiplied by the strength of each antibiotic according to Thai-FDA market authorisation identification number. The market authorisation identification number and ATCvet codes were used to categorise different active ingredients of antibiotics used in the medicated feed and verified with Thai-FDA database. Consumption of each active ingredient was classified into different stages of pig production: breeding pig, pig less than $25 \mathrm{~kg}$ and fattener.

\section{Interviews with veterinarians in the feed industry}

To gain a deeper understanding of medicated feed we conducted in-depth interviews with veterinarians working in the feed mill industry. As there was no list or systematic way to approach all potential participants directly, we solicited the help of the TFMA to identify veterinarians fulfilling the following criteria: (1) they could provide information about the use of antibiotics in animal feed, (2) they had worked in the animal feed area for more than 10 years and (3) they were willing to be interviewed. Five veterinarians have met these criteria identified by the TFMA.

All interviews were conducted face-to-face in Thai by the researchers (AL and VT) between October 2018 and December 2018 using a semi-structured interview guide with three sections: common antibiotics mixed in feed including type, dosage and duration of use; common diseases and pathogens and common conditions in pigs that require the use of antibiotics. The interviews were 
audio-recorded and lasted between 1.5 to 2 hours. The key informants were also asked to complete a one-page closedended questionnaire and return it online within 14 days.

\section{Data management and analysis}

The interview audio recording was transcribed verbatim and anonymised by AL. The questionnaire data were transferred to Microsoft Excel and Prism 8 for data management and visualisation. The information in relation to the use of antibiotics was plotted over a period of pigs' age in weeks according to different stages including suckling piglet, nursery pig and fatteners. The maximum or minimum dose range was reported if there were different reports from more than one veterinarian. The information was returned to the informants for review.

\section{Consent and ethical considerations}

Prior to the interviews, pig farmers and feed mills' representatives were provided with a participant information form and asked to sign an informed consent form if they agreed to participate. Veterinarians working at feed mills gave their verbal consent to take part in an interview. Permission was requested to record the interview and written notes were also taken.

The data were manually checked for completeness and for entry errors by the researcher (AL). Information including the name of respondents and feed mills were deleted from the data set. Data were protected by access authentication with only the researcher (AL) able to access the survey and interview data.

\section{Patient and public involvement}

No patients were involved in this study.

\section{RESULTS}

Pig farmer survey

Characteristics of farmers and farms

In total, 84 of 102 farmers agreed to participate (response rate $82.4 \%)$. Over half $(59.5 \%)$ were female and over two-thirds $(72.6 \%)$ owned the farm that they worked on. About two-thirds $(69.0 \%)$ of respondents were running commercial farms and the remainder were running smallholder farms. Over $60 \%$ of the farms were farrowto-finish farms and over $30 \%$ were fattening farms. Thirty-six per cent of the farms had a GAP certificate. Twenty per cent were members of cooperative farms and only $9.5 \%$ were contract farms.

One-third reported a monthly income of less than THB 10000 (US\$ 317; US\$ $1=31.5$ THB) and over half reported a significant reduction in income over the last 3 years due to oversupply and lower market prices for live pigs. Of the 84 farmers, $21.4 \%$ reported spending an average of more than THB 50000 (US\$1590) per month on purchasing feed and a third $(36.9 \%)$ reported spending an average of less than THB 1000 (US\$32) on medicines. Marketing of the animals was variable with a third of farmers using brokers (32.1\%), a fifth using pork retailers $(21.4 \%)$ and $14.3 \%$ using both brokers and
Table 1 Use of antibiotics and medicated feed, and their sources, from the farmer survey

\begin{tabular}{|c|c|c|}
\hline & $\begin{array}{l}\text { Antibiotic } \\
(\mathrm{n}=84, \%)\end{array}$ & $\begin{array}{l}\text { Medicated feed } \\
(n=84, \%)\end{array}$ \\
\hline \multicolumn{3}{|l|}{$\begin{array}{l}\text { Use of antibiotics or medicated } \\
\text { feed }\end{array}$} \\
\hline$\checkmark \quad$ Use & $62(73.8)$ & $11(13.1)^{\star}$ \\
\hline Do not use & $22(26.2)$ & $18(21.4)$ \\
\hline Do not know & - & $19(22.6)$ \\
\hline Not willing to respond & - & $36(42.9)$ \\
\hline \multicolumn{3}{|l|}{$\begin{array}{l}\text { Source of antibiotics and medicated } \\
\text { feed }\end{array}$} \\
\hline $\begin{array}{l}\text { Pharmaceutical company/ } \\
\text { feed mill }\end{array}$ & $16(25.8)$ & $2(18.2)$ \\
\hline - Pharmacy & $11(17.7)$ & - \\
\hline $\begin{array}{l}\text { Both pharmaceutical } \\
\text { company and pharmacy }\end{array}$ & $29(46.8)$ & - \\
\hline - In-house mixing & - & $8(72.7)$ \\
\hline Internet, online & - & - \\
\hline Others & $6(9.7)$ & $1(99.1)$ \\
\hline
\end{tabular}

${ }^{*}$ At least one feed formula at farm.

retailers. The remainder used a mixture of routes that mainly related to local consumption (online supplementary table A1).

Across all pig age groups, gastrointestinal infections, respiratory infections and lameness were reported at least occasionally in the previous 12 months by more than half of respondents. In suckling piglets and nursery pigs, gastrointestinal infections were reported to have occurred regularly, $34.0 \%$ and $12.2 \%$, respectively. In sows, reproductive infections were also reported as occurring by half of farmers (online supplementary figure A2).

\section{Use of antibiotics at farm}

Three-quarters of farmers reported using antibiotics, but most farmers were not willing to say that they used medicated feed or did not know whether or not the feed they used contained antibiotics. Pharmaceutical companies and pharmacies were common sources of antibiotics. The majority of farmers reported adding antibiotics to feed in-house. No farmer reported buying antibiotics or medicated feed online (table 1).

\section{Oral and injectable antibiotics for disease prevention}

About half of farmers reported using oral antibiotics (oral solution or adding solution or powder to drinking water, excluding medicated feed) and injectable antibiotics for disease prevention for the whole group. Overall, one-third of farmers reported using oral and injectable antibiotics in the CIA group. Half of the farmers used only one active ingredient in each stage of pig production (table 2A,B).

In total, farmers reported using 11 different antibiotic active ingredients for disease prevention. Although amoxicillin was the most commonly reported, about half 
Table 2 Number of farms, by type of pig, reporting (A) use of oral and injectable antibiotics for prevention, (B) number of different types of active ingredient used and (C) active ingredient categorised by WHO CIA list from the farmer survey

\begin{tabular}{|c|c|c|c|c|c|}
\hline \multirow[b]{2}{*}{ (A) Number (\%) of farms } & \multirow[b]{2}{*}{$\begin{array}{l}\text { All farms } \\
(n=84)\end{array}$} & \multicolumn{4}{|c|}{ By type of pig in farm (no. of farms) } \\
\hline & & $\begin{array}{l}\text { Sow } \\
(\mathrm{n}=54)^{*}\end{array}$ & $\begin{array}{l}\text { Suckling pig } \\
(\mathrm{n}=54)^{*}\end{array}$ & $\begin{array}{l}\text { Nursery pig } \\
(\mathrm{n}=54)^{*}\end{array}$ & Fattener $(n=84)$ \\
\hline $\begin{array}{l}\text { Reporting any use of antibiotics for } \\
\text { prevention }\end{array}$ & $48(57.1)$ & $31(36.9)$ & $26(31.0)$ & $17(20.2)$ & $26(31.0)$ \\
\hline \multirow{2}{*}{$\begin{array}{l}\text { Reporting any use of Critically } \\
\text { Important Antimicrobials for human } \\
\text { medicine for prevention }\end{array}$} & $26(31.0)$ & $17(31.5)$ & $11(20.4)$ & $9(16.7)$ & $14(16.7)$ \\
\hline & $\begin{array}{l}\text { All farms } \\
(\mathrm{n}=48) \dagger\end{array}$ & $\begin{array}{l}\text { Sow } \\
(n=31)\end{array}$ & $\begin{array}{l}\text { Suckling pig } \\
(\mathrm{n}=26)\end{array}$ & $\begin{array}{l}\text { Nursery pig } \\
(n=17)\end{array}$ & $\begin{array}{l}\text { Fattener } \\
(\mathrm{n}=26)\end{array}$ \\
\hline \multicolumn{6}{|c|}{ (B) Number (\%) different types of active ingredient used } \\
\hline One active ingredient & $24(50.0)$ & $21(67.7)$ & $19(73.1)$ & $9(52.9)$ & $15(57.7)$ \\
\hline Two active ingredients & $12(25.0)$ & $3(9.7)$ & $5(19.2)$ & $6(35.2)$ & 5 (19.2) \\
\hline Three active ingredients & $6(12.5)$ & $4(12.9)$ & $2(7.1)$ & $2(11.8)$ & $2(7.7)$ \\
\hline Four active ingredients & $6(12.5)$ & $3(9.7)$ & - & - & $4(15.4)$ \\
\hline \multicolumn{6}{|c|}{ (C) Number of farms (\%) reporting use of named active ingredients (WHO ATCvet code) } \\
\hline \multicolumn{6}{|c|}{ (I) Critically important antimicrobials - highest priority } \\
\hline Ceftiofur (QJ01DD90) & $2(4.2)$ & - & - & - & $2(7.7)$ \\
\hline Enrofloxacin (QJ01MA90) & $11(22.9)$ & $4(12.9)$ & $6(23.1)$ & $5(29.4)$ & $9(34.6)$ \\
\hline \multicolumn{6}{|c|}{ (II) Critically important antimicrobials - high priority } \\
\hline Amoxicillin (QJ01CA04) & $19(39.6)$ & $15(48.4)$ & $5(19.2)$ & $7(41.2)$ & $7(26.9)$ \\
\hline Gentamicin (QJ01GB03) & $1(2.1)$ & - & - & - & $1(3.8)$ \\
\hline Kanamycin (QJ01GB04) & $3(6.3)$ & $3(9.7)$ & $2(7.7)$ & 0 & $3(11.5)$ \\
\hline Streptomycin (QJ01GA01) & $1(2.1)$ & $1(3.2)$ & - & - & \\
\hline \multicolumn{6}{|l|}{ (III) Highly important antimicrobials } \\
\hline Chloramphenicol (QJ01BA01) & $1(2.1)$ & $1(3.2)$ & $1(3.8)$ & - & - \\
\hline Lincomycin (QJ01FF02) & $5(10.4)$ & $3(9.7)$ & $1(3.8)$ & $4(23.5)$ & $4(15.4)$ \\
\hline $\begin{array}{l}\text { Penicillins, combinations with } \\
\text { other antibacterials (QJ01RA01) }\end{array}$ & $6(12.5)$ & $5(16.1)$ & $4(15.4)$ & $1(5.9)$ & $4(15.4)$ \\
\hline Tetracycline (QJ01AA07) & $6(12.5)$ & $5(16.1)$ & $1(3.8)$ & $2(11.8)$ & $2(7.7)$ \\
\hline \multicolumn{6}{|l|}{ (IV) Important antimicrobials } \\
\hline Tiamulin (QJ01XQ01) & $3(6.3)$ & $2(6.5)$ & - & - & $1(3.8)$ \\
\hline Unknown & $22(45.8)$ & $11(35.5)$ & $10(38.5)$ & $8(47.1)$ & $11(42.3)$ \\
\hline
\end{tabular}

${ }^{\star}$ Number of farms reporting raising pigs in this stage.

†Number of farms reporting antibiotic use for prevention.

ATCvet, veterinary anatomical therapeutic chemical; WHO CIA list, WHO list of Critically Important Antimicrobials for Human Medicine.

of farmers could not specify the name of the antibiotic used, either by trade name or active ingredient (table 2C)

\section{Source of advice}

Of all farmers, $81 \%$ reported having received advice on animal health, $77.4 \%$ on antibiotic administration and $42.9 \%$ on the use of feed. It is worth noting that most farmers sought advice on animal health management $(45.6 \%)$, antibiotics $(45.8 \%)$ and feed $(44.4 \%)$ from 'others'. These were unqualified sources such as relatives, peers, other farmers or someone they called 'doctor' who may or may not have been a veterinarian. Pharmaceutical companies and feed mills were also a source of advice for farmers (online supplementary file 2 table A2).
Factors associated with the use of antibiotics for prevention

The farmers' characteristics that appear to be risk factors for using antibiotics for prevention in the past 12 months are shown in table 3 . The use of antibiotics for prevention of disease was significantly associated with farmers' experience in raising pigs, farm income, farm type, having received advice on animal health and belonging to a farm cooperative.

\section{Feed mill survey}

Characteristics of feed Mills

Of the 238 questionnaires distributed, 31 were returned (response rate 13\%). However, it is estimated that the 31 feed mills that did participate in the survey, account for 
Table 3 Factors associated with the use of antibiotics for prevention of disease in the past 12 months from the farmer survey

\begin{tabular}{|c|c|c|c|c|c|}
\hline Characteristics & Categories & $\begin{array}{l}\text { Number of farms } \\
\text { with data available }\end{array}$ & $\begin{array}{l}\text { Use of antibiotic } \\
\text { for prevention (\%) }\end{array}$ & OR $(95 \% \mathrm{Cl})$ & P-value \\
\hline \multirow{2}{*}{$\begin{array}{l}\text { Farmer's highest } \\
\text { level of education }\end{array}$} & Primary school & 37 & $17(46.0)$ & rv & \\
\hline & $\begin{array}{l}\text { Secondary school } \\
\text { and higher }\end{array}$ & 47 & $30(63.8)$ & $2.28(0.92-5.65)$ & 0.10 \\
\hline \multirow[t]{2}{*}{ Farmer's experience } & $\leq 10$ years & 37 & $16(43.3)$ & rv & \\
\hline & $>10$ years & 47 & $31(66.0)$ & $2.82(1.01-8.08)$ & $0.04^{*}$ \\
\hline \multirow{2}{*}{$\begin{array}{l}\text { Farmer's knowledge } \\
\text { a }\end{array}$} & Score $<60 \%$ & 29 & $14(48.3)$ & rv & \\
\hline & Score $\geq 60 \%$ & 52 & $32(61.5)$ & $1.86(0.72-4.75)$ & 0.19 \\
\hline \multirow[t]{2}{*}{ Size of farm } & Smallholder farm & 26 & $11(42.3)$ & rv & \\
\hline & Commercial farm & 58 & $36(62.1)$ & $2.54(0.96-6.71)$ & 0.05 \\
\hline \multirow[t]{2}{*}{ Type of farm } & $\begin{array}{l}\text { Farrowing to } \\
\text { finisher farm }\end{array}$ & 54 & $37(68.5)$ & rv & \\
\hline & Fattening & 30 & $10(33.3)$ & $0.33(0.12-0.87)$ & $0.02^{*}$ \\
\hline \multirow[t]{2}{*}{ GAP certified farm } & No & 53 & $26(49.1)$ & rv & \\
\hline & Yes & 31 & $21(67.7)$ & $2.54(0.96-6.71)$ & 0.05 \\
\hline \multirow{2}{*}{$\begin{array}{l}\text { Member of } \\
\text { cooperative farm }\end{array}$} & No & 67 & $33(49.3)$ & rv & \\
\hline & Yes & 17 & $14(82.4)$ & $7.73(1.49-40.01)$ & $0.01^{*}$ \\
\hline \multirow[t]{2}{*}{ Contracted farm } & No & 76 & $42(55.3)$ & rv & \\
\hline & Yes & 8 & $5(62.5)$ & $1.28(0.28-5.80)$ & 0.75 \\
\hline \multirow[t]{2}{*}{$\begin{array}{l}\text { Household income } \\
\text { per month }\end{array}$} & $\begin{array}{l}\text { Less than BHT } \\
50,000\end{array}$ & 47 & $21(44.7)$ & $\mathrm{rv}$ & \\
\hline & $\begin{array}{l}\text { More than BHT } \\
50,000\end{array}$ & 23 & $18(78.3)$ & $4.46(1.32-15.05)$ & $0.01^{*}$ \\
\hline \multirow[t]{2}{*}{$\begin{array}{l}\text { Advice on animal } \\
\text { health }\end{array}$} & $\begin{array}{l}\text { Not receiving } \\
\text { advice }\end{array}$ & 16 & 5 (31.3) & rv & \\
\hline & Receiving advice & 68 & $42(61.8)$ & 3.78 (1.12-12.73) & $0.02^{*}$ \\
\hline
\end{tabular}

*Statistically significant at $\mathrm{p}<0.05$.

†Knowledge: five true/false statements in relation to the use of antibiotics and AMR, taken from the AMR module in the 2017 National Health Welfare survey form.

AMR, antimicrobial resistance; GAP, Good Agriculture Practice; rv, reference value.

approximately $80 \%$ of the total national production of pig feed (data from a market survey via personal communication). Twenty-five out of the 31 participating feed mills reported that they had added antibiotics to some feeds in 2017, while the remaining 6 feed mills denied having done so.

Use of medicated feed

Based on the analysis of the feed mill survey data, the total amount of active ingredients mixed into medicated feed for pigs was 843 tonnes in 2017 (table 4). Among these, the top three active ingredients were amoxicillin, contained in almost half of feeds, then halquinol and tiamulin. Of the total production, $64.3 \%$ of medicated feed contained antibiotics on the CIA group, including an estimated total of over 40 tonnes of colistin.

Of the total amount of antibiotics added in medicated feed, $39.7 \%$ was targeted at suckling and nursery pigs, followed by fatteners $(37.3 \%)$ and breeding pigs $(23.0 \%)$. Regarding choices of antibiotics across the different stages of pig production, the majority of colistin $(87.2 \%)$ and haquinol $(60.4 \%)$ were intended for suckling and nursery pigs, while the majority of tylosin $(81 \%)$, lincomycin $(61.7 \%)$ and tiamulin $(44.3 \%)$ was added to feed for fatteners. Most bacitracin (87.6\%) and oxytetracycline $(83.5 \%)$ were added to feed for sows (figure 1 ).

\section{Feed industry veterinarian interviews}

All five of the animal feed industry veterinarians who were interviewed had practised in the animal feed field for more than 20 years (maximum=37 years). They were asked to explain the use of common antibiotics in relation to common diseases and common management at different stages of pig production (by week) (figure 2). Amoxicillin and tiamulin were commonly recommended for use at all stages; the dose range was between 300 and 
Table 4 Amounts of active ingredients mixed in medicated feed from the feed mill survey, categorised by WHO CIA list

Amount of antibiotic added to medicated feed in $\mathbf{k g}$

\begin{tabular}{|c|c|c|c|c|}
\hline \multirow[b]{3}{*}{$\begin{array}{l}\text { Active ingredient (WHO ATCvet } \\
\text { code) }\end{array}$} & \multicolumn{4}{|c|}{ Amount of antibiotic added to medicated feed in $\mathbf{k g}$} \\
\hline & \multirow[b]{2}{*}{$\begin{array}{l}\text { All feeds } \\
(\mathbf{k g}, \%)\end{array}$} & \multicolumn{3}{|c|}{ By stage of pig production } \\
\hline & & $\begin{array}{l}\text { Feeds for breeding } \\
\text { pig (sow) }\end{array}$ & $\begin{array}{l}\text { Feeds for pigs }<25 \mathrm{~kg} \\
\text { (suckling and nursery pigs) }\end{array}$ & $\begin{array}{l}\text { Feeds for } \\
\text { fatteners }\end{array}$ \\
\hline $\begin{array}{l}\text { (I) Critically important antimicrobials } \\
\text { highest priority }\end{array}$ & $145805.3(17.3)$ & 18487.3 & 62399.5 & 64918.6 \\
\hline Colistin (QA07AA10) & $40378.5(4.8)$ & 2251.7 & 35209.4 & 2917.4 \\
\hline Fosfomycin (QJ01XX01) & $767.2(0.1)$ & 79.6 & 11.2 & 676.4 \\
\hline Kitasamycin (QJ01FA93) & $9435.4(1.1)$ & 2153.7 & 588.9 & 6692.9 \\
\hline Tilmicosin (QJ01FA91) & $54738.9(6.5)$ & 10271.0 & 21045.6 & 23422.3 \\
\hline Tylosin (QJ01FA90) & $38507.1(4.6)$ & 1764.2 & 5543.5 & 31199.4 \\
\hline Tylvalosin (QJ01FA92) & $1978.2(0.2)$ & 1967.1 & 0.9 & 10.2 \\
\hline $\begin{array}{l}\text { (II) Critically important antimicrobials } \\
\text { high priority }\end{array}$ & $395971.6(47.0)$ & 102994.7 & 152266.0 & 140710.9 \\
\hline Amoxicillin (QJ01CA04) & $395950.1(47.0)$ & 102994.7 & 152244.5 & 140710.9 \\
\hline Apramycin (QJ01GB90) & $21.5(<0.1)$ & - & 21.5 & - \\
\hline (III) Highly important antimicrobials & $48328.3(5.7)$ & 17851.5 & 11247.7 & 19229.0 \\
\hline Chlortetracycline (QJ01AA03) & $32889.4(3.9)$ & 11853.7 & 7515.2 & 13520.4 \\
\hline Doxycycline (QJ01AA02) & $2686.6(0.3)$ & 1661.2 & 881.7 & 143.7 \\
\hline Lincomycin (QJ01FF02) & $7881.0(0.9)$ & 270.9 & 2749.2 & 4860.9 \\
\hline Oxytetracycline (QJ01AA06) & $4871.3(0.6)$ & 4065.7 & 101.6 & 704 \\
\hline Sulfadimidine (QJ01EQ03) & $240.2(0.1)$ & - & 24.0 & 216.1 \\
\hline (IV) Important antimicrobials & $128519.1(15.3)$ & 41809.6 & 33433.7 & 53275.9 \\
\hline Bacitracin (QA07AA93) & $9285.3(1.1)$ & 8136.5 & 710.1 & 438.7 \\
\hline Tiamulin (QJ01XQ01) & $119233.8(14.2)$ & 33673.1 & 32723.6 & 52837.2 \\
\hline $\begin{array}{l}\text { (V) Antimicrobial classes currently not } \\
\text { used in humans }\end{array}$ & $123707.1(14.7)$ & 12763.9 & 74844.6 & 36098.7 \\
\hline Avilamycin (QA07AA95) & $281.5(<0.1)$ & - & 143.0 & 138.6 \\
\hline Bambermycin (QA07AA96) & $78.2(<0.1)$ & - & 78.2 & - \\
\hline Halquinol (QA07A×91) & $123347.4(14.6)$ & 12763.9 & 74623.4 & 35960.1 \\
\hline Total & 842571.7 & 193906.9 & 334215.5 & 314449.2 \\
\hline
\end{tabular}

ATCvet, veterinary anatomical therapeutic chemical; WHO CIA list, WHO list of Critically Important Antimicrobials for Human Medicine.

400 ppm (1 ppm equivalent to $1 \mathrm{mg}$ of active ingredient per $1 \mathrm{~kg}$ of feed) and 150 and $200 \mathrm{ppm}$, respectively. Halquinol and colistin were commonly recommended for addition to medicated feed for suckling piglets and nursery pigs for the prevention of gastrointestinal tract infection. Tylosin, tilmicosin and chlortetracycline were recommended for fatteners. According to the indication label on feed packages and veterinary supervision, the duration of antibiotic use was commonly about 4 to 6 weeks. No medicated feed was said to be provided to fatteners 1 month prior to slaughter $\left(20^{\text {th }}\right.$ to $24^{\text {th }}$ week).

The veterinarians reported that the choice of active ingredients in the feed was designed for both treatment and prevention of common diseases and animal health management at different stages of pig production, particularly when the animals are under stress or prone to infection. For example, during the first week, piglets undergo teeth and tail clippings and castration. During the second week, pigs start having feed and are weaned in the fourth week. The feed is changed at the fifth, ninth, thirteenth and nineteenth weeks. Between the second and seventh week, pigs are vaccinated against common infectious diseases. These procedures, including handling animals and movement between pens, cause pigs stress.

\section{DISCUSSION}

\section{Use of antibiotics by different active ingredients}

To our knowledge, this is one of the first studies to assess in detail antibiotic use in pig production in a low- or middle-income country. This study indicated that amoxicillin, a broad-spectrum antibiotic, was the most used oral and injectable antibiotic for prevention of disease (39.6\% of total farms) and in the medicated feed $(47 \%$ of the total amount of antibiotics). The national surveillance consumption data confirm that amoxicillin was 


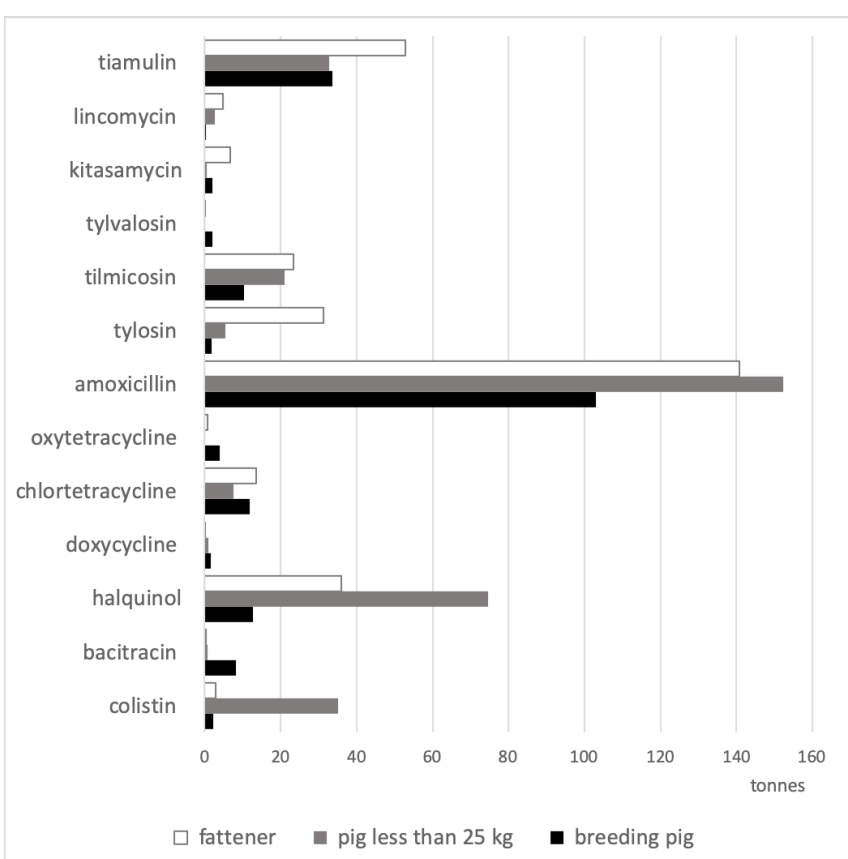

Figure 1 Amount (tonnes) of active ingredients mixed in medicated feed from the feed mill survey, by stage of pig production (antibiotics including 1 tonne at less of the active ingredient).

the most used antibiotic in both humans and animals, and that a quarter $(24.6 \%)$ of total consumption was in animals. ${ }^{16}$ In animals, amoxicillin is reportedly widely used for prophylaxis and treatment of generalised infections in many countries. ${ }^{18} 19$ However, when given orally to pigs via medicated feed, absorption and bioavailability are low ${ }^{20-23}$. This may lead to chronic exposure of gut microbiota to amoxicillin and an associated high selective pressure in the intestine of animals, making them more likely to develop antibiotic resistance. ${ }^{24}$

Our previous reviews observed differences in antibiotic use among stages of pig production, mainly due to differences in diseases, epidemiology and administration route of the available drugs. ${ }^{19}$ In this study, gastrointestinal infection reportedly mostly affects suckling piglets and nursery pigs. These are periods when pigs are most susceptible to getting diarrhoea from common pathogens such as post-weaning $E$. coli and salmonellosis. The use of colistin in pigs has been shown to lead to the development of a plasmid-mediated colistin-resistant gene in humans in China. ${ }^{725}$ Consequently, in 2018, DLD restricted the use of colistin for disease prevention in livestock, and farmers replaced it with halquinol. Halquinol is not used in humans and not listed on the WHO CIA list. It is now widely used in pig and poultry production for prevention control and treatment of diarrhoea caused or complicated by E. coli and Salmonella spp in pigs. However, the maximal residue limit of halquinol has not been established by Codex Alimentarius due to a lack of information about the characterisation of residues in animal tissues. ${ }^{26} 27$

Feed industry veterinarians considered that the use of antibiotics in the fattening period for disease prevention was crucial for farms, particularly those which could not effectively control common diseases. Antibiotics were used in the medicated feed for fatteners, including lincomycin, tiamulin and tylosin. Tylosin belongs to the macrolides class of antibiotics and is classified as a highest priority CIA. Macrolides are used to treat infections in humans and are also reserved as second-line treatments

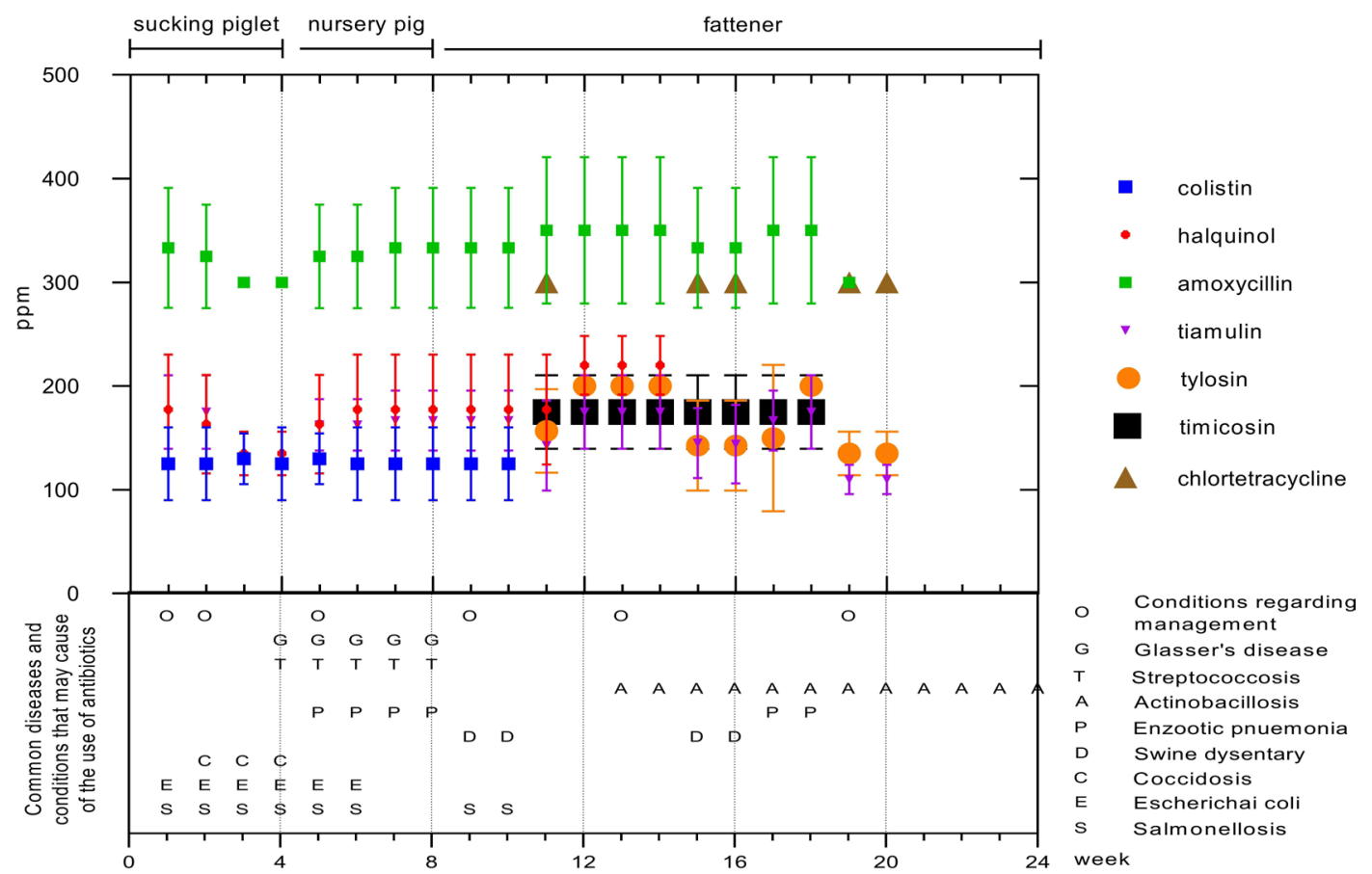

Figure 2 Common active ingredients in medicated feed, dose and duration of use, synthesised from the interview with veterinarians. 
for patients who are allergic to penicillins ${ }^{28}$ Resistance to macrolides in human enterococci and enterococci from animal sources in Europe ${ }^{2930}$ has been well documented. High levels of resistance to tylosin in several bacteria including zoonotic pathogens are also reported in pigs in many European Union countries; for example, $43 \%$ to $59 \%$ of Streptococcus suis isolates are tylosin resistant in the UK, ${ }^{31}$ and $69 \%$ of all pathogens collected from pigs in 2017 are resistant to tylosin in France. ${ }^{32}$ In Thailand, a high level of S.suis isolates resistant to erythromycin (belonging to macrolides class) $(80.9 \%)$ were found in human patients and pigs. ${ }^{33}$ Other potential zoonotic bacteria such as Salmonella spp showed a high level of resistance to common antibiotics including tetracycline $(82.6 \%)$ and ampicillin $(81.4 \%)$ in Thailand. In food chain, $53.7 \%$ of Salmonella and $60.6 \%$ of E. coli are resistant to ampicillin. Resistance of E. coli to colistin is low, $3 \%$ and none are resistant to meropenem. ${ }^{34}$

\section{Use of antibiotics at farm level}

Our results show that $57.1 \%$ of farmers reported the use of oral and injectable antibiotics for prevention. Common sources of antibiotics for farmers were pharmacies and pharmaceutical companies. In Thailand, most antibiotics are classified as dangerous drugs, which do not require a prescription but do need to be dispensed by licensed pharmacists or veterinarians at licensed pharmacies; a few are classified as 'special control medicines' and require a prescription. In 2017, there were about 24000 retailers and wholesalers licensed for pharmaceutical sales. ${ }^{35}$ This large number of antibiotic sellers serving human health needs provides easy access to antibiotics for use in animals. In addition, pharmacists may have limited knowledge about pig disease and farm management due to the absence of veterinary medicine content in the pharmacist undergraduate syllabus.

Pharmaceutical companies can sell antibiotics to livestock producers through veterinarians (mostly in commercial farms). Therefore, veterinarians are likely to play a dual role as animal healthcare providers and drug distributors leading to a conflict of interest where they make a direct profit from the sales of medical products including antibiotics. In the Netherlands, the government decoupled the functions of prescription from the selling of drugs by veterinarians. ${ }^{36}$ There is currently no similar intervention in Thailand to address the potential financial incentives for both veterinarians and pharmacists to sell medical products for animals.

\section{Factors influencing the use of antibiotics in farms}

Farmers' number of years' experience and belonging to a farm cooperative were associated with the use of antibiotics for prevention. Experienced farmers may have an established protocol or programme of using antibiotics without a detailed examination of animals' health conditions. Belonging to a farm cooperative probably increased the opportunity among farmers to exchange information about animal health and antibiotic use. Some studies have found that the opinions of peers affected farmers' decision-making on antibiotic use. ${ }^{37-39}$ In addition, farms with higher incomes were more likely to use antibiotics for prevention, perhaps reflecting greater ability to purchase.

The majority of farmers reportedly received advice on animal health and antibiotic use from unqualified sources, possibly contributing to the positive correlation between advice on animal health and high level of antibiotic use for prevention in this study. Other studies have shown that farmers perceive veterinarians to be the most trusted information source on disease control ${ }^{40}$ and influence their decisions. ${ }^{3841}$

However, other risk factors with a lower impact may not have been detected. Possible factors associated with antibiotic use for prevention reported in other studies include the density of pig population in the area and the number of pigs on the farm, ${ }^{42-44}$ production systems, ${ }^{45}$ the type of farm ${ }^{134647}$ and pig age groups. ${ }^{12} 4849$

\section{Medicated feed}

In this study, based on data from the feed mill survey, the largest proportion of medicated feed was applied to suckling and nursery pigs (39.7\%) and fatteners (37.3\%), similar to some other studies. ${ }^{48-50}$ This study estimated that at a national level, the total volume of antibiotics mixed into pig feed was around 843 tonnes. The 2017 national antimicrobial consumption report ${ }^{16}$ states that a total 3690 tonnes of veterinary antimicrobials were used by all food-producing animals, of which 2007 tonnes (54\%) was premix for medicated feed however these data do not provide a breakdown by animal type. Our estimation from the feed mill survey is likely to be an underestimate of the true volume of antibiotics in medicated feed due to a number of reasons. One being that many farmers add antibiotics to the feed in-house at the farm level. For example, the farm survey indicated that $72.7 \%$ of farmers produced their own medicated feed using mixers. In addition, the mix of medicated feed in farms implies a lack of quality control in ensuring homogeneous distribution of antibiotics in the feed, a concern also in Europe. ${ }^{51}$ This is an area which requires effective regulation.

\section{Policy implications}

The majority of antibiotics added to the medicated feed (64.3\% of total amount of medicated feed) and used as oral and injectable medications at farm level $(31 \%$ of total farms) belonged to the category of Critically Important Antimicrobials for human health. Recently in March 2018, in response to the AMR threat, the DLD stipulated that medicated feed can only be produced, sold and used with a veterinary prescription. It also prohibited the addition of five classes of antibiotics (polymyxin, penicillins, fluoroquinolones, fosfomycin and cephalosporins) to medicated feed for disease prevention. Additionally, cephalosporins are not allowed in medicated feeds for any indications. ${ }^{52}$ 
In order to promote antibiotic stewardship in animal health, the use of antibiotics should be based on guidelines with clear guidance on the indication for use, choice of antibiotic, dose and duration and these should be based on local microbiological surveillance data. Where possible non-WHO CIA list antibiotics should be recommended, and where this is not possible then antibiotics in the lower tiers on this list should be recommended first. Ideally, the use of antibiotics in the CIA category should be limited to treatment, with specific indications and only when there is no lower tier alternative. However, one challenge is that there are currently very few such guidelines available in veterinary field, especially in low- and middleincome countries. ${ }^{53}$ The development and dissemination of such guidelines is an important priority. ${ }^{54}$

For disease prevention, ideally the use of antibiotics should be avoided according to the WHO and European Union guidelines for the use of antibiotics in animals. ${ }^{1055}$ For alternatives to antibiotics, farmers may consider improving husbandry and farm management such as good ventilation, good feed quality and water and farm bio-security. Vaccinations are likely to play an important role in reducing the risk of infection and the need for antibiotics for prevention. The use of probiotics or prebiotics and immunomodulators such as natural herbal remedies have also been proposed as alternatives. ${ }^{56}$

\section{Limitations}

This study had some limitations. First, as described in our recent review, there is no standard approach to collecting data on the volume of antibiotics used on farms, and a wide range of methods have been applied for example farm-based survey, inspection of discarded antibiotic packaging in bins and veterinary prescription data. ${ }^{57}$ In high-income countries where recording systems are available at farms, antibiotic prescription or treatment records are the most common sources of farm-level data on antibiotic use. These provide accurate data on the type of antibiotic, indications, doses and duration, the number of animals receiving antibiotics and can inform the relationship between antibiotic use and antibiotic resistance. However, none of these data collection methods were applicable in this study: antibiotic treatment and medicated feed use were often not recorded; feed packages lacked labels and counting discarded packages of antibiotics was not feasible (online supplementary figure A1). The collection of on-farm data is thus a great challenge in a country such as Thailand, and demanded the mixed methods used here. Changing the regulations to require a prescription is critical to improved audit data.

Second, apart from the large proportion of farmers who did not know if they used antibiotics in feed as the feed package did not label antibiotic content, a large proportion of farmers were not willing to disclose this. In 2018, the DLD issued a new regulation which mandated all feed mills to print on all medicated feed the antibiotics' names and concentration (PPM), and all farmers were required to keep records of veterinary prescriptions and administration. This should help in the monitoring of antibiotic use on farms, if the regulation is effectively enforced and monitored.

The third challenge was the sample representativeness. For reasons of feasibility, the survey of pig farms was conducted in only one province. Additionally, the list of pig farms was out of date and many farms especially smallholder farms had closed down due to a significant reduction in the market price for pigs over the last few years. This meant that it was difficult to conduct a random selection of farms across the province and instead a complete sampling of farms in selected subdistricts was carried out. However, the full range of farm types was included: from smallholder farms with only a few pigs through to large commercial farms with thousands of pigs and the province with one of the highest number of farms was chosen. Moreover, an outbreak of African swine fever was reported in neighbouring countries ${ }^{58}$ over the data collection period, probably affecting the willingness to be part of the study. Due to a small sample size, only univariate analysis could be conducted, and it revealed that the use of antibiotics in pig farms was significantly associated with certain farm characteristics such as belonging to a farm cooperative, type of farm and farmer's income.

Nonetheless, this study covered 84 pig farms with a high response rate of $82.4 \%$. Of 18 farmers who did not participate in the study, 12 smallholder farmers $(26 \%$, $12 / 46$ farmers in the studies areas) and 6 commercial farmers $(11 \%, 6 / 56$ farmers in the studies areas). In terms of geographical distribution, among six subdistricts, the response rate in two subdistricts was $100 \%$ and about $90 \%$ in other three subdistricts. The response rate was low in only one subdistrict $(38 \%)$ (online supplementary file 3 tableA1). The results are therefore likely to represent a significant proportion of pig production in the province, and meaningful conclusions about farmers' antibiotic use in the studied province can be drawn.

Besides, the farm survey data was supplemented by data from the feed mill survey. Although only 31 feed mills participated, they included the large agro-industrial conglomerates responsible for an estimated $80 \%$ of the national production of medicated feed and are therefore an important target for future interventions.

\section{CONCLUSION}

This is one of the first studies outside high-income countries to obtain information on the critical question of antibiotic use in pig farming. It used multiple approaches to investigate the use of antibiotics in pig production in Thailand. From the data, we established patterns of antibiotic use and estimated consumption of antibiotics through farmer and feed mill surveys. Our results clearly show the majority of antibiotics used in Thai pig farms are considered the Highest and High Priority Critically Important Antimicrobials for human health according to the WHO-CIA list, with concerning implications in terms of the potential for AMR in pigs and humans. 
We recommend progressive restriction in the use of antibiotics, in particular, those highest tier on the WHO CIA list. This includes through controlling distribution by reclassifying certain antibiotics as prescription-only medicines and restricting the use of CIA for specific indications and guided by local microbiological and sensitivity evidence. The DLD should strengthen the veterinary service system at all levels to improve access of farmers, smallholder farms in particular, to quality animal health information and potential alternative interventions to antibiotic use including farm management improvement, vaccines and immunomodulators.

Alternative solutions need to be carefully tested for their cost-effectiveness in comparison to the antibiotics they would replace. Those solutions with the greatest impact need to be demonstrated to the farmers in order to build confidence in new solutions. Future studies about factors contributing to the use of antibiotics are required to fill these important knowledge gaps and introduce effective policies.

Twitter Angkana Lekagul @angkanasw

Acknowledgements The authors acknowledge the data collection support provided by the International Health Policy Program, Thai-FDA, DLD, Provincial Health Office, Provincial Livestock Office and TFMA. We thank all the respondents that took their time to respond to the survey and particularly the interviewees. We would like to extend a special thanks to Dr Suwit Wibulpolprasert, Dr Walaiporn Patcharanarumol and Dr Sopon lamsirithaworn for their great support during the period of the study. We gratefully acknowledge the support from Professor Suvichai Rojanasthien, Associate Professor Prapas Patchanee, Assistant Professor Terdsak Yano, Assistant Professor Panuwat Yamsakul and Assistant Professor Pakpoom Tadee, Faculty of Veterinary Medicine, Chiang Mai University for the piloting. We are grateful to Associate Professor Dr Supon Limwattananon and Dr Vuthiphan Vongmongkol for help with statistical analysis and Waraporn Poungkantha, Parinda Seneerattanaprayul, Oranutt Raengna, Wanwisa Kaewkhankhaeng and Pigunkaew Sinam for assistance with logistic arrangement during the fieldwork. We also would like to thank the journal for waiving article processing charges.

Contributors AL, VT and SY contributed to the design of the study. AM and JR provided conceptual and technical support in the study design and data interpretation phases. AL conducted the data collection and analysis and developed the initial draft of the manuscript. AL, VT and SY substantively reviewed and revised successive drafts. All authors approved the final manuscript.

Funding The study was funded by the Thailand Ministry of Public Health and US CDC collaboration, the Coordinating Unit for One Health, Department of Disease Control, Ministry of Public Health and the Thailand Science Research and Innovation (TSRI) under the senior research scholar on Health Policy and System Research (contract no. RTA6280007).

Competing interests None declared.

Patient consent for publication Not required.

Ethics approval The study protocol was approved by the Research Ethics Committee at the Thai Ministry of Public Health's Institute for Development of Human Research (reference number: IHRP2018007) and the London School of Hygiene and Tropical Medicine (reference number: 14860).

Provenance and peer review Not commissioned; externally peer reviewed.

Data availability statement Data are available upon request. The questionnaire survey form is available within the article supplementary material. Due to the ethically sensitive nature of the research, interview transcripts will be made available to researchers only, on condition they provide evidence of ethics approval and sign a consent form. Other data that support the findings of this study are available on request from the corresponding author.

Open access This is an open access article distributed in accordance with the Creative Commons Attribution Non Commercial (CC BY-NC 4.0) license, which permits others to distribute, remix, adapt, build upon this work non-commercially, and license their derivative works on different terms, provided the original work is properly cited, appropriate credit is given, any changes made indicated, and the use is non-commercial. See: http://creativecommons.org/licenses/by-nc/4.0/.

\section{REFERENCES}

1 European Centre for Disease Prevention and Control (ECDC), European Food Safety Authority (EFSA), European Medicines Agency (EMA). ECDC/EFSA/EMA second joint report on the integrated analysis of the consumption of antimicrobial agents and occurrence of antimicrobial resistance in bacteria from humans and food-producing animals joint Interagency antimicrobial consumption and Resistanc. EFSA J 2017;15:4872.

2 World Health Organization. Critically important antimicrobials for human medicine [Internet]. Geneva, 2017. Available: http://apps. who.int/iris/bitstream/handle/10665/255027/9789241512220eng.pdf;jsessionid=FC65DF119DE54907C6E5D457093EC97E? sequence $=1$ [Accessed 20 Apr 2018].

3 World Health Organisation. WHO list of Critically Important Antimicrobials for Human Medicine (WHO CIA list) [Internet], 2019. Available: https://www.who.int/foodsafety/publications/ antimicrobials-sixth/en/ [Accessed 19 Dec 2019].

4 Nhung N, Cuong N, Thwaites G, et al. Antimicrobial usage and antimicrobial resistance in animal production in Southeast Asia: a review. Antibiotics 2016;5:37.

5 McCrackin MA, Helke KL, Galloway AM, et al. Effect of antimicrobial use in agricultural animals on drug-resistant foodborne campylobacteriosis in humans: a systematic literature review. Crit Rev Food Sci Nutr 2016;56:2115-32.

6 Burow E, Rostalski A, Harlizius J, et al. Antibiotic resistance in Escherichia coli from pigs from birth to slaughter and its association with antibiotic treatment. Prev Vet Med 2019;165:52-62.

7 Liu Y-Y, Wang Y, Walsh TR, et al. Emergence of plasmid-mediated colistin resistance mechanism MCR-1 in animals and human beings in China: a microbiological and molecular biological study. Lancet Infect Dis 2016;16:161-8.

8 Van Boeckel TP, Brower C, Gilbert M, et al. Global trends in antimicrobial use in food animals, 2015. Available: www.pnas.org/ cgi/doi/10.1073/pnas.1503141112 [Accessed 27 May 2019].

9 Landers TF, Cohen B, Wittum TE, et al. A review of antibiotic use in food animals: perspective, policy, and potential. vol. 127, public health reports. Association of Schools of Public Health 2012:4-22.

10 World Health Organization. WHO guidelines on use of medically important antimicrobials in food-producing animals [Internet]. Geneva, 2017. Available: https://apps.who.int/iris/bitstream/handle/ 10665/258970/9789241550130-eng.pdf;jsessionid=A706500C3E5E 73F4C29C17C3117EBAB2? sequence $=1$ [Accessed 29 Oct 2019].

11 Filippitzi ME, Callens B, Pardon B, et al. Antimicrobial use in pigs, broilers and veal calves in Belgium. Vlaams Diergeneeskundig Tijdschrift 2014;83:214-24.

12 Callens B, Persoons D, Maes D, et al. Prophylactic and metaphylactic antimicrobial use in Belgian fattening pig herds. Prev Vet Med 2012;106:53-62.

13 Merle R, Mollenhauer Y, Hajek P, et al. Monitoring of antibiotic consumption in pigs on agricultural farms. Berliner und Munchener Tierarztliche Wochenschrift 2013;126:326-32.

14 van Rennings L, von Münchhausen C, Ottilie H, et al. CrossSectional study on antibiotic usage in pigs in Germany. PLoS One 2015;10:e0119114. [Internet].

15 Rajić A, Reid-Smith R, Deckert A, et al. Antibiotic use in swine farms in Alberta - A reply [2]. Canadian Veterinary Journal 2006;47:1153.

16 Thai working group on Health Policy and Systems Research on antimicrobial resistance. Consumption of antimicrobial agents in Thailand in 2017 First report [Internet], 2018. Available: http:// inppthaigov.net/DB/publication/attachresearch/421/chapter1.pdf

17 Department of Livestock Development. Number of livestock inventory in Thailand 2017 [Internet]. Bangkok, 2018. Available: http://ict.dld.go.th/th2/index.php/th/report/529-report-thailandlivestock/reportservey2560/1241-2560-1-country

18 De Briyne N, Atkinson J, Borriello SP, et al. Antibiotics used most commonly to treat animals in Europe. Veterinary Record 2014;175:325 http://veterinaryrecord.bmj.com/

19 Lekagul A, Tangcharoensathien V, Yeung S. Patterns of antibiotic use in global pig production: a systematic review. Veterinary and Animal Science 2019;7:100058 https://www.sciencedirect.com/science/ article/pii/S2451943X18302473?via\%3Dihub

20 Kidsley AK, Abraham S, Bell JM, et al. Antimicrobial susceptibility of Escherichia coli and Salmonella spp. isolates from healthy pigs in Australia: results of a pilot national survey. Front Microbiol 2018;9:1207.

21 Nsofor CA, Odom CM. Distribution and antibiotics susceptibility pattern of staphylococcus aureus isolated from pigs in Ahiara, Imo 
state Nigeria, 2018. Available: https://www.semanticscholar.org/ paper/Distribution-and-antibiotics-susceptibility-pattern-NsoforOdom/19ccc400d808b7e6cb2332692ee3a1bd83ba0857 [Accessed $21 \mathrm{Mar} 2019]$.

22 Ramos F, Coimbra J, Boison C, et al. Amoxicillin [Internet]. Available: http://www.fao.org/fileadmin/user_upload/vetdrug/docs/12-2012amoxicillin.pdf [Accessed 21 Mar 2019].

23 Reyns T, De Boever S, Schauvliege S, et al. Influence of administration route on the biotransformation of amoxicillin in the pig. J Vet Pharmacol Ther 2009;32:241-8 http://doi.wiley.com/10. 1111/j.1365-2885.2008.01033.x

24 Burch DGS, Sperling D. Amoxicillin-current use in swine medicine. $J$ Vet Pharmacol Ther 2018;41:356-68. [Internet].

25 Li X-shen, Liu B-guang, Dong P, et al. The prevalence of mcr -1 and resistance characteristics of Escherichia coli isolates from diseased and healthy pigs. Diagn Microbiol Infect Dis 2018;91:63-5 https:// linkinghub.elsevier.com/retrieve/pii/S0732889317304108

26 JEFCA-Joint Food and Agriculture Organization of the United Nations (FAO)/World Health Organization (WHO) Expert Committee on Food Additives. Evaluation of certain veterinary drug residues in food [Internet]. Vol. 988, World Health Organization Technical Report Series, 2014. Available: http://www.who.int/bookorders [Accessed 21 Mar 2019].

27 Codex Alimentarius Commission. Joint FAO / WHO Food Standards Programme, Codex Alimentarius Commission - Twenty-seventh session report of the 25th session of the Codex Committee on Nutrition and Foods for Special Dietary Uses, 2001. Available: https://www.anses.fr/fr/system/files/report-ccrvdf.pdf [Accessed 21 Mar 2019].

28 Kanoh S, Rubin BK. Mechanisms of action and clinical application of macrolides as immunomodulatory medications. Clin Microbiol Rev 2010;23:590-615. [Internet].

29 Miller WR, Munita JM, Arias CA. Mechanisms of antibiotic resistance in enterococci HHS public access. Expert Rev Anti Infect Ther 2014;12:1221-36. [Internet].

30 López F, Culebras E, Betriú C, et al. Antimicrobial susceptibility and macrolide resistance genes in Enterococcus faecium with reduced susceptibility to quinupristin-dalfopristin: level of quinupristindalfopristin resistance is not dependent on erm(B) attenuator region sequence. Diagn Microbiol Infect Dis 2010;66:73-7 www. sciencedirect.com

31 UK-VARSS. UK Veterinary Antibiotic Resistance and Sales Surveillance Report 2017 [Internet]. Addlestone, 2018. Available: https://assets.publishing.service.gov.uk/government/uploads/ system/uploads/attachment data/file/750811/_1473963-v1-UKVARSS_2017_Report_FINAL.pdf [Accessed 3 Äpr 2019].

32 Anses. RESAPATH - French surveillance network for antimicrobial resistance in bacteria from diseased animals - 2017 Annual report [Internet], 2019. Available: https://www.anses.fr/en/system/files/ LABO-Ra-Resapath2017EN.pdf [Accessed 3 Apr 2019].

33 Yongkiettrakul S, Maneerat K, Arechanajan B, et al. Antimicrobial susceptibility of Streptococcus suis isolated from diseased pigs, asymptomatic pigs, and human patients in Thailand. BMC Vet Res 2019;15:5.

34 National Steering Committee on Antimicrobial Resistance. Thailand's One Health Report on Antimicrobial Consumption and Antimicrobial Resistance in 2018, 2019.

35 Sommanustweechai $\mathrm{A}$, Chanvatik S, Sermsinsiri V, et al. Antibiotic distribution channels in Thailand: results of key-informant interviews, reviews of drug regulations and database searches. Bull World Health Organ 2018;96:101-9.

36 Speksnijder DC, Mevius DJ, Bruschke CJM, et al. Reduction of veterinary antimicrobial use in the Netherlands. The Dutch success model. Zoonoses Public Health 2015;62:79-87.

37 Alarcon P, Rushton J, Nathues $\mathrm{H}$, et al. Economic efficiency analysis of different strategies to control post-weaning multi-systemic wasting syndrome and porcine circovirus type 2 subclinical infection in 3-weekly batch system farms. Prev Vet Med 2013;110:103-18.

38 Garforth C, Rehman T, Mckemey K, et al. Improving the design of knowledge transfer strategies by understanding farmer attitudes and behaviour. J Farm Manag 2004;12:17-32.

39 Fischer K, Sjöström K, Stiernström A, et al. Dairy farmers perspectives on antibiotic use: a qualitative study. J Dairy Sci 2019;102:2724-37. [Internet] https://www.sciencedirect.com/ science/article/pii/S0022030219300062
40 De Briyne N, Atkinson J, Pokludová L, et al. Factors influencing antibiotic prescribing habits and use of sensitivity testing amongst veterinarians in Europe, 2013. Available: http://veterinaryrecord.bmj. com/content/vetrec/173/19/475.full.pdf [Accessed 20 Apr 2018].

41 Alarcon P, Wieland B, Mateus ALP, et al. Pig farmers' perceptions, attitudes, influences and management of information in the decision-making process for disease control. Prev Vet Med 2014;116:223-42 https://www.sciencedirect.com/science/article/pii/ S0167587713002699\#fig0005

42 MEH B, Taverne FJ, van Geijlswijk IM, et al. Consumption of antimicrobials in pigs, veal calves, and broilers in the Netherlands: quantitative results of nationwide collection of data in 2011. PLoS ONE 2013;8.

43 Stevens KB, Gilbert J, Strachan WD, et al. Characteristics of commercial pig farms in Great britain and their use of antimicrobials. Veterinary Record 2007;161:45-52.

44 Vieira AR, Pires SM, Houe H, et al. Trends in slaughter pig production and antimicrobial consumption in Danish slaughter pig herds, 2002-2008. Epidemiol Infect 2011;139:1601-9.

$45 \mathrm{Kim}$ DP, Saegerman C, Douny C, et al. First survey on the use of antibiotics in pig and poultry production in the red River delta region of Vietnam 2013;3:247-56.

46 Moreno MA. Survey of quantitative antimicrobial consumption in two different pig finishing systems. Veterinary Record 2012;171:325.

47 van der Fels-Klerx HJ, Puister-Jansen LF, van Asselt ED, et al. Farm factors associated with the use of antibiotics in pig production1. $J$ Anim Sci 2011;89:1922-9 http://www.animalsciencepublications. org/publications/jas/abstracts/89/6/1922

48 Chauvin C, Beloeil P-A, Orand J-P, et al. A survey of group-level antibiotic prescriptions in pig production in France. Prev Vet Med 2002;55:109-20.

49 Sjölund M, Postma M, Collineau L, et al. Quantitative and qualitative antimicrobial usage patterns in farrow-to-finish pig herds in Belgium, France, Germany and Sweden. Prev Vet Med 2016;130:41-50. [Internet].

50 Jensen VF, Emborg HD, Aarestrup FM. Indications and patterns of therapeutic use of antimicrobial agents in the Danish pig production from 2002 to 2008. J Vet Pharmacol Ther 2012;35:33-46.

51 European Commission. Commission staff working document impact ass essment accompanying the document to regulation of the European parliament and of the council on the manufacture, placing on the market and use of medicated feed and repealing Council Directive 90/167/EEC [Internet], 2014. Available: https://ec.europa. eu/food/sites/food/files/safety/docs/animal-feed-medic-12328 impact assesment en.pdf [Accessed 5 Apr 2019].

52 Department of Livestock Development Ministry of Agriculture and Cooperatives. Notification of the Department of Livestock Development: Medicated feed which not allow to be produced, imported, sold and used [Internet], 2018. Available: http://afvc.dld. go.th/index.php/2016-04-12-04-46-53/กฎหมาย/พระราชบัญญัติควบคุม

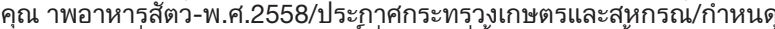
ลักษณะและเงื่อนไขของอาหารสัตวที่ผสมยาที่ห้ามผลิต-นำเข้า-ขาย-และใช้ พ.ศ.2561/

53 World Veterinary Association, World Organisatin for Animal Health. Summary of the results of the WVA/OIE survey on actions to reduce the emergence and spread of antimicrobial resistance (AMR) in animals 2018.

54 European Union. Guidelines for the prudent use of antimicrobials in veterinary medicine [Internet]. Official Journal of the European Union, 2015. Available: http://ec.europa.eu/food/food/biosafety/ antimicrobial resistance/index en.htm\%0Ahttps://ec.europa.eu/ health//sites/health/files/antimicrobial_resistance/docs/2015_ prudent_use_guidelines_en.pdf [Accessed 8 Dec 2019].

55 Guidelines for the prudent use of antimicrobials in veterinary medicine. Practical examples. [Internet]. Brussels, 2015. Available: https://ec.europa.eu/health//sites/health/files/antimicrobial_ resistance/docs/2015_prudent_use_guidelines_annex_en.pdf [Accessed $20 \mathrm{Apr}$ 2018].

56 Cheng G, Hao H, Xie S, et al. Antibiotic alternatives: the substitution of antibiotics in animal husbandry? Front Microbiol 2014;5.

57 Lekagul A, Tangcharoensathien V, Yeung S. The use of antimicrobials in global pig production: a systematic review of methods for quantification. Prev Vet Med 2018;160:85-98.

58 Wang T, Sun Y, Qiu H-J. African swine fever: an unprecedented disaster and challenge to China. Infectious Diseases of Poverty 2018;7:111 